Fishing Resources / Aquaculture Received on: 07/03/2020

Accepted on: 20/08/2020

\title{
Dietary garlic essential oil on development parameters of severum post-larvae
}

Óleo essencial de alho sobre os parâmetros de desenvolvimento de pós-larvas de acará severo

\author{
CAMPELO, Daniel Abreu Vasconcelos ${ }^{* 1}$ \\ 0000-0001-9204-3566
}

GONÇALVES, Isis Silva ${ }^{1}$

0000-0003-3765-5337

SILVA, Isamaira Costa $\mathrm{e}^{1}$

0000-0002-5583-3224

\author{
DE MOURA, Lorena Batista ${ }^{2}$ \\ 0000-0002-9225-6390
}

BRABO, Marcos Ferreira ${ }^{1}$

000-001-8179-9886

BARBAS, Luis André Luz ${ }^{3}$

0000-0002-2708-8909

VERAS, Galileu Crovatto ${ }^{4}$

0000-0002-9975-830X

${ }^{1}$ Universidade Federal do Para, Instituto de Estudos Costeiros, Faculdade de Engenharia de Pesca, Alameda Leandro Ribeiro s/n $\mathrm{n}^{\circ}, 68600-000$, Bragança, PA, Brasil. ${ }^{2}$ Universidade Federal Rural da Amazônia, Faculdade de Agronomia, Tv. Pau Amarelo s/nº, 68650-000, Capitão Poço, PA, Brasil.

${ }^{3}$ Instituto Federal de Educação Ciência e Tecnologia do Pará, Laboratório de Aquacultura de Espécies Tropicais, BR 316, Km 61 - Saudade II - Cristo Redentor s/no ${ }^{\circ}$ 68740-970, Castanhal, PA, Brasil.

${ }^{4}$ Universidade Federal de Minas Gerais, Escola de Veterinária, Laboratório de Aquicultura, Avenida Presidente Antônio Carlos n 6627, 31270-901, Belo Horizonte, MG, Brasil.

*Corresponding author: danielvc@ufpa.br

\section{ABSTRACT}

The present study aimed to evaluate the influence of garlic essential oil (GEO) on the growth performance and morphometric variables of severum (Heros severus) post-larvae. A growth trial was performed using 150 severum post-larvae $(1.6 \pm 0.03 \mathrm{mg}$ and $5.58 \pm$ $0.1 \mathrm{~mm}$ ), distributed in fifteen $1-\mathrm{L}$ aquaria, with constant aeration. The fish were essayed in a completely randomized design with five treatments, using diets containing graded levels of GEO $\left(0.00,0.05,0.50,1.00\right.$ and $\left.1.50 \mathrm{~g} \mathrm{~kg}^{-1}\right)$ and three replicates. The diets were offered four times a day, until apparent satiation, for 30 days. At the end of the experiment, the fish were counted, weighed and measured, to evaluate growth performance and morphometric variables. Increased diet levels of GEO resulted in a linear reduction in growth performance parameters, except for the survival rate, weight and length uniformity of the batch, and morphometric variables which did not present significant differences. Elevated concentrations of dietary GEO may be detrimental to larvae and post-larvae of fish, which could be more sensitive to the potential damage that high concentrations of this essential oil may cause. Therefore, the inclusion of GEO in levels above $0.05 \mathrm{~g} \mathrm{~kg}^{-1}$ in diets for severum post-larvae is not recommended. 
Keywords: Allium sativum, amazonian fish, larval rearing, plant extracts.

\section{RESUMO}

O presente estudo teve como objetivo avaliar a influência do óleo essencial de alho (OEA) sobre o desempenho produtivo e as variáveis morfométricas de pós-larvas de acará severo (Heros severus). Foi realizado ensaio de crescimento com 150 pós-larvas severas $(1,6 \pm$ $0,03 \mathrm{mg}$ e 5,58 $\pm 0,1 \mathrm{~mm}$ ), distribuídas em quinze aquários de $1 \mathrm{~L}$, com aeração constante. Os peixes foram distribuídos em delineamento inteiramente casualizado com cinco tratamentos, dietas contendo diferentes níveis de OEA $\left(0,00 ; 0,05 ; 0,50 ; 1,00\right.$ e $1,50 \mathrm{~g} \mathrm{~kg}^{-}$ ${ }^{1}$ ) e três repetições. As dietas foram oferecidas quatro vezes ao dia, até saciedade aparente, por 30 dias. Ao final do experimento, os peixes foram contados, pesados e medidos, para avaliação do desempenho produtivo e das variáveis morfométricas. $\mathrm{O}$ aumento dos níveis de OEA na dieta resultou em redução linear nos parâmetros de desempenho produtivo, com exceção da taxa de sobrevivência e uniformidade de peso e comprimento do lote, que não apresentaram diferenças significativas, assim como as variáveis morfométricas. Concentrações elevadas de OEA na dieta podem ser prejudiciais para larvas e pós-larvas de peixes, que podem ser mais sensíveis ao dano potencial que altas concentrações deste óleo essencial podem causar. Portanto, a inclusão de OEA em níveis acima de $0,05 \mathrm{~g} \mathrm{~kg}^{-}$ 1 em dietas para pós-larvas de acará severo não é recomendada.

Palavras-chave: Allium sativum, extratos vegetais, larvicultura, peixe amazônico.

\section{INTRODUCTION}

The severum (Heros severus) is among the Amazonian fish that have potential as an ornamental species. It stands out for its bright yellowish color, good adaptation to fish tank environments and easily spawning under captivity (Favero et al., 2010; Alishahi et al., 2014). In natural occurrence sites, severum feeds on small invertebrates and plant material (Alishahi et al., 2014), whereas in captivity it can readily accept industrialized diet.

The post-larvae stage is a critical period in early fish farming, in which most of the fish's biological system is not entirely developed, hence being sensitive to many types of stressors. Thus, to improve general health status, different products are often used in aquaculture as prophylactic, therapeutic or even as growth promoters (Rico et al., 2013). On the other hand, the use of synthetic products may cause numerous side effects in the environment and human health, and in some cases, with limited efficacy (Gabor et al., 2010).

In search for alternatives, natural products can possibly drive synthetic products and growth promoters out of use (Gabor et al., 2010). Several ingredients with proven efficacy for nutritional, growth promotion and immunostimulation for aquatic organisms (Bricknell and Dalmo, 2005) are characterized as functional ingredients (Roberfroid, 2002). Thus, the use of those feedstuff for fish diets can become a good strategy to minimize stress and enhance growth performance (Xue et al., 2008; Abdel-Khalil and Khalil, 2014; Reverter et al., 2014). In this context, essential oils (EOs) which are natural products formed by a mixture (Baser et al., 2007) of hydrophobic liquids containing volatile aromatic compounds from plants (Mathe, 2009), 
emerge as good functional ingredients for fish diets. Among the EOs, garlic essential oil (GEO) has caught the attention of the aquaculture sector.

Garlic (Allium sativum) is an herb available throughout the world. Previous studies on dietary garlic for fish have shown improved growth, survival, and protection against pathogenic organisms (Lee and Gao, 2012; Lee et al., 2012; Talpur and Ikhwanuddin, 2012). Garlic has been studied not only in the form of an EO, but also as different extracts, such as aqueous and powder (Shin and Kim, 2004), and their benefits are ascribed to a variety of organosulfur compounds within these extracts, especially the allicin (Augusti et al., 1974).

Plant-derived products, as garlic essential oil, are promising sources of bioactive molecules, less costly and readily available (Bulfon et al., 2015). However, negative effects on survival and growth of aquatic animals fed with dietary garlic have also been reported (Huang et al., 2001; Xiang and Liu, 2002). Therefore, the present study aimed to evaluate the development of the Amazonian ornamental fish severum post-larva fed dietary garlic essential oil.

\section{MATERIAL AND METHODS}

The experiment was approved by the Ethics Committee on the Use of Animals of the Federal University of Pará, CEUA/UFPA (Protocol no 7656100517) and conducted at the Laboratory of Ornamental Fish of the Federal University of Pará, Bragança - PA.

To perform the experiment, a total of 150 7-day-old severum post-larvae, with mean body weight and standard length of
$1.60 \pm 0.03 \mathrm{mg}$ and $5.58 \pm 0.19 \mathrm{~mm}$, respectively, were distributed in fifteen $1-\mathrm{L}$ aquariums, at a density of 10 postlarvae $\mathrm{L}^{-1}$. The post-larvae were hatched in the Laboratory of Ornamental Fish, under controlled environmental conditions. All aquariums were maintained with constant aeration at a photoperiod adjusted to $12 \mathrm{~h}$ Light: $12 \mathrm{~h}$ Dark, using fluorescent lamps (60W). The aquariums were siphoned once a day to remove uneaten food and faeces, then replenished with fresh water.

A completely randomized design with five treatments and three replicates was used. A basal diet was formulated to contain $40 \%$ crude protein and $4500 \mathrm{kcal}$ $\mathrm{kg}^{-1}$ gross energy (Table 1) and separated into five parts for the inclusion of the test ingredient. The garlic essential oil (GEO) was acquired from a commercial establishment (Biotae ${ }^{\circledR}$, Tatuí, SP, Brazil) and kept refrigerated $\left(4^{\circ} \mathrm{C}\right)$ until use. Thereafter, the GEO was included mixed with soybean oil in the diet at levels of $0.00,0.05,0.50,1.00$ and 1.50 $\mathrm{g} \mathrm{kg}^{-1}$. Then, the diets were moistened, with $25 \%$ water at $50^{\circ} \mathrm{C}$, manually mixed and pelleted in an electric meat grinder (G.PANIZ, MCR-22, São Paulo, SP, Brazil), dried in a forced air oven (QUIMIS, São Paulo, SP, Brazil) at $35^{\circ} \mathrm{C}$ for $24 \mathrm{~h}$, and stored in a refrigerator, at $4^{\circ} \mathrm{C}$. Before the feeding trial, all diets were crushed in a mill and manually sieved, so that granulometry of the pellets could adequately fit into the postlarvae mouth. Post-larvae were fed to apparent satiation, moment at which animals showed no interest in the diet, four times daily, at 08:00, 11:00, 14:00 and 17:00h, for a period of 30 days. 
Table 1. Formulations and proximate compositions of the experimental diets

\begin{tabular}{|c|c|}
\hline Ingredient & $\mathrm{g} \mathrm{kg}^{-1}$ \\
\hline Soybean meal & 540.00 \\
\hline Fish meal & 180.00 \\
\hline Corn meal & 120.00 \\
\hline Wheat bran & 90.00 \\
\hline Soybean oil & 35.80 \\
\hline Dicalcium phosphate & 15.00 \\
\hline Mineral and vitamin $\operatorname{mix}^{1}$ & 8.00 \\
\hline DL-methionine & 6.00 \\
\hline Salt & 5.00 \\
\hline $\mathrm{BHT}^{2}$ & 0.20 \\
\hline \multicolumn{2}{|c|}{ Proximate compositions ${ }^{3}$} \\
\hline Crude Protein $(\%)$ & 40.76 \\
\hline Ether extract (\%) & 7.07 \\
\hline Mineral Material (\%) & 10.20 \\
\hline Gross energy $\left(\mathrm{kcal} \mathrm{kg}^{-1}\right)$ & 4504.00 \\
\hline \multicolumn{2}{|c|}{$\begin{array}{l}{ }^{1} \text { Guaranteed levels per kilogram of product: Vit. A, 1,200.000 UI ; Vit. D3; 200,000 UI ; Vit. E, } \\
12,000 \mathrm{mg} \text {; Vit. K3, 2,400 mg; Vit. B1, 4,800 mg ; Vit. B2, 4,800 mg; Vit. B6, 4,000 mg; Vit. } \\
\text { B12, 4,800 mg; Ac. Folic, 1,200 mg; Calcium pantothenate, 12,000 mg; Vit. C, 48,000 mg; Biotin, } \\
48 \mathrm{mg} \text {; Cholin, 65,000 mg; Niacin, 24,000 mg; Fe, 10,000 mg; Cu, 6,000 mg; Mg, 4,000 mg; Zn, } \\
6,000 \mathrm{mg} \text {; I, } 20 \mathrm{mg} \text {; Co, } 2 \mathrm{mg} \text {; Se, } 20 \mathrm{mg} .\end{array}$} \\
\hline
\end{tabular}

During the experimental period, water quality parameters such as temperature $\left(26.86 \pm 0.3{ }^{\circ} \mathrm{C}\right)$ and dissolved oxygen $\left(6.98 \pm 0.7 \mathrm{mg} \mathrm{L}^{-1}\right)$ were monitored daily, whereas the $\mathrm{pH}(6.94 \pm 0.3)$ and total ammonium concentration $(0.05 \pm$ $\left.0.03 \mathrm{mg} \mathrm{L}^{-1}\right)$ was monitored every two days. Temperature and dissolved oxygen were measured with a thermometer and a digital oximeter (Lutron DO -5510, São Paulo, SP, Brazil), total ammonia and $\mathrm{pH}$ were measured with a multi-parameter device (HI 3512, Hanna Instruments, Barueri, SP, Brazil).

At the end of the feeding trial all fish were counted, weighed on a precision scale (AG200 Gehaka ${ }^{\circledR} 0.0001$ g, São
Paulo, SP, Brazil) and photographed using a digital camera (FinePIX, S2800HD, Japan). Growth performance was evaluated for final weight, weight gain (final weight - initial weight), final length, length gain (final length - initial length), specific growth rate ((ln final weight - ln initial weight) days $\left.{ }^{-1}\right)$ x 100), weight and length uniformity of the batch and survival rate. To determine the batch uniformity, the following equation by Furuya et al. (1998) was used: $U=(\mathrm{N}$ $\pm 20 \%$ )/Nt $) X$ 100, where: $U=$ the uniformity of the batch, i.e. variation in weight or total length $(\%) ; \mathrm{Nt}=$ the total number of fish in each experimental unit; and $\mathrm{N} \pm 20 \%=$ the number of animals 
with weight or total length $\pm 20 \%$ of the mean for each experimental unit. The fish photographs were analyzed using an image analysis package (ImageProPlus ${ }^{\circledR}$ ), for determination of the following length and morphometric variables: standard length, head length, trunk length, post-anal length, head height, body height and eye diameter.

For the verification of normality and homogeneity of variances, data were submitted to Lilliefors and Bartlett's tests, respectively. After assumptions were satisfied, a one-way analysis of variance (ANOVA) at 5\% significance was performed. When differences were observed a regression analysis, between dietary GEO level and growth parameters was used. To adjust the equations, the values of each experimental unit were used. To choose the most suitable regression model, the significance of the regression coefficients, the magnitude of the coefficients of determination and the biological response of each variable were considered. Statistical analyses were performed using SPSS (SPSS Inc., Chicago, IL, USA).

\section{RESULTS}

Dietary GEO affected $(\mathrm{P}<0.05)$ the final weight, weight gain, final length, length gain and specific growth rate of severum post-larvae. The weight and length uniformity of the batch and the survival rate were the only parameters of growth performance that were not influenced $(P$ $>0.05)$ by the levels of GEO in the diets (Table 2).

Table 2. Growth performance of severum (Heros severus) post-larvae fed increasing levels of dietary garlic essential oil (GEO)

\begin{tabular}{lcccccc}
\hline \multirow{2}{*}{$\begin{array}{l}\text { Growth } \\
\text { performance }\end{array}$} & 0.00 & 0.05 & 0.50 & 1.00 & 1.50 & P-value \\
\cline { 2 - 7 } FW (mg) & $9.53 \pm 2.1$ & $10.15 \pm 2.3$ & $8.93 \pm 0.5$ & $8.86 \pm 1.1$ & $7.09 \pm 0.8$ & 0.0303 \\
WG (mg) & $7.93 \pm 2.1$ & $8.55 \pm 2.3$ & $7.33 \pm 0.5$ & $7.26 \pm 1.1$ & $5.49 \pm 0.8$ & 0.0152 \\
FL (mm) & $6.75 \pm 0.5$ & $6.86 \pm 0.4$ & $6.58 \pm 0.2$ & $6.57 \pm 0.2$ & $6.35 \pm 0.1$ & 0.0339 \\
LG (mm) & $1.17 \pm 0.5$ & $1.28 \pm 0.4$ & $1.00 \pm 0.2$ & $0.99 \pm 0.2$ & $0.77 \pm 0.1$ & 0.0339 \\
SGR (\%) & $5.31 \pm 0.7$ & $5.52 \pm 0.6$ & $5.20 \pm 0.2$ & $5.16 \pm 0.4$ & $4.48 \pm 0.3$ & 0.0231 \\
UW (\%) & $55.77 \pm 2.0$ & $52.38 \pm 4.1$ & $51.85 \pm 3.2$ & $54.88 \pm 3.8$ & $55.56 \pm 9.6$ & 0.6744 \\
UL (\%) & $100.00 \pm 0.0$ & $100.00 \pm 0.0$ & $100.00 \pm 0.0$ & $100.00 \pm 0.0$ & $100.00 \pm 0.0$ & 0.4515 \\
SR (\%) & $70.00 \pm 13.3$ & $70.00 \pm 10.0$ & $73.33 \pm 15.6$ & $66.67 \pm 11.1$ & $73.33 \pm 17.8$ & 0.1870 \\
\hline
\end{tabular}

Values are presented as mean $\pm \mathrm{SD}(\mathrm{n}=3)$. Significant differences were determined by analysis of variance (ANOVA) followed by linear regression analysis. FW (Final weight); WG (Weight gain); FL (Final length); LG (Length gain); SGR (Specific growth rate); UW (Uniformity of weight); UL (Uniformity of length); SR (Survival rate).

According to the linear regression analysis, increased dietary GEO levels led to decreased final weight, weight gain, final length, length gain and specific growth rate (Figure 1). 

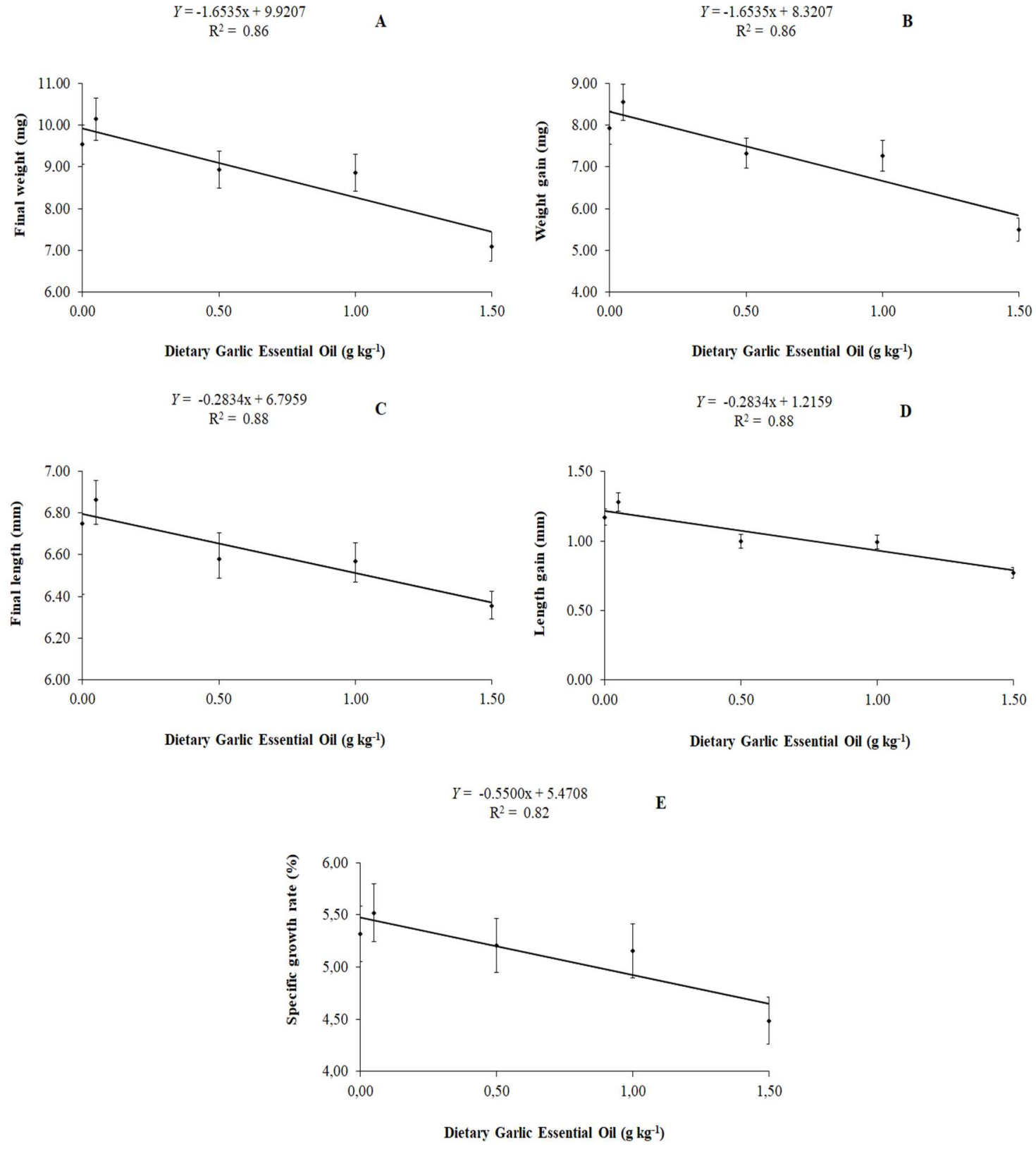

Figure 1. Dietary garlic essential oil for H. severus post-larvae, based on linear regression analysis of final weight (A), weight gain (B), final length (C), length gain (D) and specific growth rate $(\mathrm{E})$.

Dietary GEO did not influence $(\mathrm{P}>0.05)$ the morphometric variables measured. However, numerically, these variables followed the same trend as those observed for growth performance. The higher the level of GEO, the lower the values of standard length, head length, trunk length, post-anal length, head height, body height and eye diameter were (Table 3). On the other hand, a numerical increase in all parameters evaluated was observed in fish receiving the lowest dose of GEO $\left(0.05 \mathrm{~g} \mathrm{~kg}^{-1}\right)$. 
Table 3. Morphometric variables of severum (Heros severus) post-larvae fed increasing levels of dietary garlic essential oil (GEO)

\begin{tabular}{lcccccc}
\hline \multirow{2}{*}{$\begin{array}{l}\text { Morphometric } \\
\text { variables }\end{array}$} & 0.00 & 0.05 & 0.50 & 1.00 & 1.50 & P-value \\
\cline { 2 - 7 } SL (mm) & $6.75 \pm 0.5$ & $6.86 \pm 0.4$ & $6.58 \pm 0.2$ & $6.57 \pm 0.2$ & $6.35 \pm 0.1$ & 0.5670 \\
HL (mm) & $2.05 \pm 0.2$ & $2.24 \pm 0.2$ & $2.06 \pm 0.1$ & $2.04 \pm 0.1$ & $1.97 \pm 0.1$ & 0.1233 \\
TL (mm) & $4.72 \pm 0.3$ & $4.63 \pm 0.1$ & $4.52 \pm 0.1$ & $4.53 \pm 0.1$ & $4.38 \pm 0.0$ & 0.2586 \\
PAL (mm) & $2.67 \pm 0.1$ & $2.70 \pm 0.1$ & $2.57 \pm 0.0$ & $2.57 \pm 0.0$ & $2.53 \pm 0.0$ & 0.4016 \\
HH (mm) & $2.08 \pm 0.1$ & $2.08 \pm 0.1$ & $1.97 \pm 0.1$ & $1.89 \pm 0.1$ & $1.81 \pm 0.1$ & 0.1536 \\
BH (mm) & $2.12 \pm 0.2$ & $2.23 \pm 0.2$ & $2.07 \pm 0.1$ & $2.08 \pm 0.1$ & $2.01 \pm 0.1$ & 0.1417 \\
ED (mm) & $1.41 \pm 0.4$ & $1.09 \pm 0.1$ & $1.00 \pm 0.1$ & $1.03 \pm 0.0$ & $0.94 \pm 0.0$ & 0.1683 \\
\hline
\end{tabular}

Values are presented as mean \pm SD $(n=3)$. SL (Standard length); HL (Head length); TL (Trunk length); PAL (Post-anal length); HH (Head height); BH (Body height); ED (Eye diameter).

\section{DISCUSSION}

Garlic extracts, which are a rich source of allicin, have shown a wide spectrum of antibacterial, antiviral, antiprotozoal and antifungal properties (Guo et al., 2012), with an associated potential to improve diets digestibility and fish growth performance (Lee and Gao, 2012). However, in the present study, according to the linear regression analysis, increased dietary GEO levels led to impaired development of severum post-larvae.

Different results were found by Jegede (2012), who observed the highest specific growth rate and feed efficiency, in red belly tilapia (Tilapia zillii) fingerlings fed $20 \mathrm{~g} \mathrm{~kg}^{-1}$ of dietary garlic powder. Similarly, Lee et al. (2014) reported significantly increased growth performance in fingerling sterlet sturgeon (Acipenser ruthenus) supplemented with $30 \mathrm{~g} \mathrm{~kg}^{-1}$ of dietary garlic powder. On the other hand, orange-spotted grouper (Epinephelus coioides) fed only $0.13 \mathrm{~g} \mathrm{~kg}^{-1}$ of dietary aqueous garlic extract showed an increment in weight gain and feed efficiency, but when supplemented with
$0.40 \mathrm{~g} \mathrm{~kg}^{-1}$, the same parameters were lower (Guo et al. 2012).

Many reports have documented the effect of garlic or allicin as growth promoters. Khalil et al. (2001) observed that allicin could improve digestion by enhancing the performance of the intestinal flora, thereby improving the utilization of energy and growth. However, most research efforts have been directed to the assessment of fresh garlic powder and just a few ones evaluating dietary GEO for fish fingerlings and juvenile (Aly and Mohamed, 2010; Woo et al., 2010; Diab et al., 2002).

Garlic powder has a lower concentration of allicin when compared to other garlic extracts, such as essential oils or aqueous extract (Guo et al., 2012), and it can be used in higher concentrations in fish diets. Thus, the effects of garlic depend on its presentation and concentration, fish species and development stage. Despite the wide margin of safety in the use of plant extracts, there are only a few reports on their negative impacts to fish farming (Syahidah et al., 2015). Juvenile hybrid tilapia (Oreochromis niloticus $\mathrm{x}$ Oreochromis aureus) fed $0.5 \mathrm{~g} \mathrm{~kg}^{-1}$ dietary garlic powder decreased weight 
gain by $20 \%$ compared to fish fed control diet, i.e. without the addition of garlic (Ndong and Fall, 2011). Rice field eel (Monopterus albus) fed $800 \mathrm{mg} \mathrm{kg}^{-1}$ of composed allicin died after three days of feeding (Huang et al., 2001) and juvenile red bellied pacu (Colossoma barchypomum), also receiving a diet containing composed allicin, had a reduction in growth rate (Xiang and Liu, 2002).

The most toxic components of allicin degradation are diallyl disulfide and diallyl trisulfide (Zhao et al., 2013; Marengoni et al., 2017). Moreover, degradation products of organosulfur compounds can be toxic when high concentrations thereof reach the intestines, interfering with normal metabolism, suppressing mitosis, leading to slow growth and even fish death (Shakya and Labh, 2014). For fish post-larvae, which do not have a fully formed digestive tract yet (Portella and Dabrowski, 2008), these compounds can be even more harmful, as suggested by the present study.

Normally, fingerlings support higher concentrations of allicin than the postlarvae. Larvae and post-larvae are highly sensitive organisms to stress, mainly because of their undeveloped immune systems (Mohamed et al., 2012). Many authors have attempted to examine the impacts of various essential oils and other plant derivatives on fish, but information regarding the effects of these products during the larval stage, especially the effects of garlic extracts on the growth performance of the larvae is scarce (Hassaan and Soltan, 2016).

The inclusion of $1.0 \mathrm{ml} \mathrm{kg}^{-1}$ GEO in the diet of Nile tilapia larvae, with an initial weight of $1.88 \pm 0.12 \mathrm{~g}$, resulted in increased growth and improvement in haematological and biochemical parameters (Hassaan and Soltan, 2016). Nile tilapia larvae with initial weight of $20 \mathrm{mg}$, fed $40 \mathrm{~g} \mathrm{~kg}^{-1}$ of dietary garlic powder, presented a higher survival rate than larvae fed without the addition of garlic, but had no improvement in weight gain (Aly et al., 2010). For Caspian roach (Rutilus rutilus) larvae weighing $1.0 \pm$ $0.07 \mathrm{~g}$, the supply of $15 \mathrm{~g} \mathrm{~kg}^{-1}$ dietary garlic powder impaired weight gain and specific growth rate, compared to larvae that received diets containing 5 and $10 \mathrm{~g}$ $\mathrm{kg}^{-1}$ garlic (Ghahderijani et al., 2016). The severum post-larvae used in the present study had an initial weight of 1.6 $\pm 0.03 \mathrm{mg}$ and received the diets supplemented with GEO during the first feeding. Thus, the results of the present study suggest that dietary GEO may not be a good strategy for early feeding fish and larviculture improvement.

Studies on the efficacy of garlic to treat fish parasites and as immunostimulants are commonplace in literature. Schelkle et al. (2013) suggest that parasites are directly affected by garlic, rather than indirectly via enhanced host immune function. Furthermore, the immunostimulating properties of garlic may disappear when high concentrations of garlic are provided (Ndong and Fall, 2011; Ghahderijani et al., 2016). Nya et al. (2010) reported that the action mechanism of allicin might well include the inhibition of cysteine protease, the scavenging and trapping of free radicals and the inhibition of thiol-containing protein in the cells of pathogens. As such, the allicin molecule can also negatively impact fish health and development, especially eggs and young forms.

Morphological observation has been recognized as a valuable tool to detect and describe body abnormalities in early life stages of fish (Koumoundouros et al. 
1997; Martinez-Montano et al. 2016). Thus, information on the morphological development of young fish is necessary to improve larvae rearing (Gisbert et al. 2002). Furthermore, fish morphometry can be affected by feed management and fish diet (Wimberger 1992). Mainly for ornamental fish species, which are marketed per unit, the influence of diet on fish morphometry is an important aspect to be evaluated (Campelo et al., 2020). In the present study, although dietary GEO reduced the productive performance of severum post-larvae, no morphological abnormality was detected.

High concentration and prolonged treatment with garlic may impair fish health, which underscores the importance of determining appropriate dosage requirements and the methods of application (Schelkle et al., 2010) for each species at each stage of life. Even minor concentration changes in dietary garlic must be monitored carefully and the professional who currently uses garlic, should be made aware of the potential harm to fish performance when using high concentrations of garlic (Schelkle et al., 2013).

The use of diets supplemented with increasing levels of garlic essential oil was detrimental to the development of severum post-larvae. Nevertheless, further evaluation of adding dietary GEO for severum post-larvae in levels close to $0.05 \mathrm{~g} \mathrm{~kg}^{-1}$ is recommended, for it could be advantageous when administered in lower concentrations.

\section{REFERENCES}

ABDEL-KHALIL, H.M.R.; KHALIL, R.H. Evaluation of two phytobiotics, Spirulina platensis and Origanumn valgare extract on growth, serum antioxidant activities and resistance of Nile tilapia (Oreochromis niloticus) to pathogenic Vibrio alginolyticus.

International Journal of Fisheries and Aquatic Studies, v.1, p.250-255, 2014.

ALISHAHI, M.; KARAMIFAR, M.; MESBAH, M.; ZAREI, M. Hematoimmunological responses of Heros severus fed diets supplemented with different levels of Dunaliella salina. Fish Physiology and Biochemistry, v.40, n.1, p.57-65, 2014.

ALY, S.M.; MOHAMED, M.F. Echinacea purpurea and Allium sativum as immunostimulants in fish culture using Nile tilapia (Oreochromis niloticus). Journal of Animal Physiology and Animal Nutrition, v. 94, p. 31-39, 2010.

ALY, S.M.; NAGGAR, G.O.E.; MOHAMED, M.F.; MOHAMED, F.M.; MOHAMED, W.E. Effect of Garlic, Echinacea, Organic Green and Vet-Yeast on Survival, Weight Gain, and Bacterial Challenge of Overwintered Nile Tilapia Fry (Orechromis niloticus). Journal of Applied Aquaculture, v.22, n.3, p.210215, 2010.

ASSOCIATION OF OFFICIAL ANALYTICAL CHEMISTS - AOAC. Official methods of analysis. 17th ed. 4th rev. Assoc. Off. Anal. Chem., Arlington, VA. 1998.

AUGUSTI, K.T.; MATHEW, P.T. Lipid lowering effect of allicin (diallyldisulphide-oxide) on long term feeding to normal rats. Cellular and Molecular Life Sciences, v.30, p.468470, 1974. 
BASER, K.H.C.; DEMIRCI, F.

Chemistry of Essential Oils. In: Berger,

R.G. (Ed), Flavours and Fragrances:

Chemistry, Bioprocessing and

Sustainability. Springer, New York, pp. 43-86, 2007.

BRICKNELL, I.; DALMO, R.A. The use of immunostimulants in fish larval aquaculture. Fish and Shellfish

Immunology, v.19, n.5, p.457-472, 2005.

BULFON, C.; VOLPATTI, D.;

GALEOTTI, M. Current research on the use of plant-derived products in farmed fish. Aquaculture Research, v.46, n.3, p.513-551, 2015.

CAMPELO, D.A.V.; DOS REIS E.R.; DIAS, B.C.B.; JUNIOR, A.D.S.P.; DOS SANTOS, L.D.; BRABO, M.F.; DE MOURA, L.B.; VERAS, G.C. Use of different feeds in larviculture of the amazon ornamental fish

Severum. Brazilian Journal of

Development, v.6, n.3, p.14035-14049, 2020.

DIAB, A.S.; EL-NAGAR, G.O.Y.M.; ABD-EI-HADY, Y.M. Evaluation of Nigella sativa L. (black seeds; baraka), Allium sativum (garlic) and Biogen as feed additives on growth performance and immunostimulants of $O$. niloticus fingerlings. Suez Canal Veterinary Medicine Journal, v.2, p.745-775, 2002.

FAVERO, J.M.D.; POMPEU, P.D.S.; PRADO-VALLADARES, A.C.

Biologia reprodutiva de Heros efasciatus Heckel, 1840 (Pisces, Cichlidae) na Reserva de Desenvolvimento Sustentável AmanãAM, visando seu manejo sustentável.
Acta Amazonica, v.40, n.2, p.373-380, 2010.

FURUYA, W.M.; SOUZA, S.R.; FURUYA, V.R.B.; HAYASHI, C.; RIBEIRO, R.P. Dietas peletizada e extrusada para machos revertidos de tilapia do Nilo (Oreochromis niloticus) na fase de terminação. Ciência Rural, v.28, n.3, p.483-487, 1998.

GABOR, E.F.; ŞARA, A.; BARBU, A. The effects of some phytoadditives on growth, health and meat quality on different species of fish. Journal of Animal Science and Biotechnology, v.43, n.1, p.61-65, 2010.

GHAHDEIJANI, M.S.; HAJIMORADLOO, A.; GHORBANI, R.; ROOHI, Z. The effects of garlicsupplemented diets on skin mucosal immune responses, stress resistance and growth performance of the Caspian roach (Rutilus rutilus) fry. Fish and Shellfish Immunology, v.49, p.79-83, 2016.

GISBERT, E.; MERINO, G.; MUGUET, J.B.; BUSH, D.; PIEDRAHITA, R.H.; CONKLIN, D.E. Morphological development and allometric growth patterns in hatcheryreared California halibut larvae.

Journal of Fish Biology, v.61, p.12171229, 2002.

GUO, J.J.; KUO, C.M.; CHUANG, Y.C.; HONG, J.W.; CHOU, R.L.; CHEN, T.I. The effects of garlicsupplemented diets on antibacterial activity against Streptococcus iniae and on growth in orange-spotted grouper, Epinephelus coioides. Aquaculture, v.364, n.5, p.33-38, 2012. 
HASSAN, M.S.; SOLTAN, M.

Evaluation of Essential Oil of Fennel and Garlic Separately or Combined with Bacillus licheniformis on the Growth, Feeding Behaviour, Hematobiochemical Indices of Oreochromis niloticus.

Journal of Aquaculture Research and Development, v.7, n.4, p.422-429, 2016.

HUANG, X.G.; HE, J.H.; ZUO, J.J. Primary research on the application effects of allicin on aquaculture of rice field eel Monopterus albus. Inland Fisheries, p.9-27, 2001.

JEGEDE, T. Effect of garlic (Allium sativum) on growth, nutrient utilization, resistance and survival of Tilapia zillii (Gervais 1852) fingerlings. Journal of Agricultural Science, v.4, n.2, p.269$274,2012$.

KHALIL, R.H.; NADIA, B.M.; SOLIMAN, M.K. Effects of Biogen and Levamisol $\mathrm{HCl}$ on the immune response of cultured Oreochromis niloticus to Aeromonas hydrophila vaccine. BeniSuef Veterinary Medicine Journal, v.11, p.381-392, 2001.

KOUMOUNDOUROS, G.; ORAN, G.; DIVANACH, P.; STEFANAKIS, S.; KENTOURI, M. The opercular complex deformity in intensive gilthead sea bream (Sparus aurata L.) larviculture. Moment of apparition and description. Aquaculture, v.156, p.165-177, 1997.

LEE, D.H.; LIM, S.R.; HAN, J.J.; LEE, S.W.; RA, C.S.; KIM, J.D. Effects of dietary garlic powder on growth, feed utilization and whole body composition changes in fingerling sterlet sturgeon, Acipenser ruthenus. Asian-
Australasian Journal of Animal

Sciences, v.27, n.9, p.1303-1310, 2014.

LEE, D.H.; RA, C.S.; SONG, Y.H.; SUNG, K.I.; KIM, J.D. Effects of dietary garlic extract on growth, feed utilization and whole body composition of juvenile starlet sturgeon (Acipenser ruthenus). Asian-Australasian Journal of Animal Sciences, v.25, n.4, p.577583, 2012.

LEE, J.Y.; GAO, Y. Review of the application of garlic, Allium sativum, in aquaculture. Journal of the World Aquaculture Society, v.43, n.4, p.447458, 2012.

MARENGONI, N.G.; PEREIRA, L.A.; WEISS, L.A.; BESEN, M.A.;

BOMBARDELLI, R.A. Garlic essential oil increases rates of eggs fertilization and hatching of Rhamdia quelen larvae in an artificial incubation system. Ciência Rural, v.47, n.6, p.1-4, 2017.

MARTÍNEZ-MONTAÑO, E.; GONZÁLEZ-ÁLVAREZ, K.; LAZO, J.P.; AUDELO-NARANJO, J.M.; VÉLEZ-MEDEL, A. Morphological development and allometric growth of yellowtail kingfish Seriola lalandi V. larvae under culture conditions.

Aquaculture Research, v.47, p.12771287, 2016.

MÁTHÉ, A.K.O.S. Essential oilsbiochemistry, production and utilisation. Phytogenics in Animal Nutrition. Natural Concepts to Optimize Gut Health and Performance, v.1, p.1-18, 2009.

MOHAMED, A.A.; EL-GALIL, A.; ABOELHADID, S.M. Trials for the 
control of trichodinosis and gyrodactylosis in hatchery reared Oreochromis niloticus fries by using garlic. Veterinary Parasitology, v.185, n.2, p.57-63, 2012.

NDONG, D.; FALL, J. The effect of garlic (Allium sativum) on growth and immune responses of hybrid tilapia (Oreochromis niloticus x Oreochromis aureus). Journal of Clinical Immunology and Immunopathology Research, v.3, n.1, p.1-9, 2011.

NYA, E.J.; DAWOOD, Z.; AUSTIN, B. The garlic component, allicin, prevents disease caused by Aeromonas hydrophila in rainbow trout, Oncorhynchus mykiss (Walbaum).

Journal of Fish Diseases, v.33, n.4, p.293-970, 2010.

PORTELLA, M.C.; DABROWSKI, K. Diets, physiology, biochemistry and digestive tract development of freshwater fish larvae. In: Cyrino, J.E.P., Bureau, D.P., Kapoor, B.G. (Eds.), Feeding and digestive functions of fishes. Science Publishers, Enfield, pp. 227-279, 2008.

REVERTER, M.; BONTEMPS, N.; LECCHINI, D.; BANAIGS, B.; SASAL, P. Use of plant extracts in fish aquaculture as an alternative to chemotherapy: Current status and future perspectives. Aquaculture, v.433, n.20, p.50-61, 2014.

RICO, A.; PHU, T.M.;

SATAPORNVANIT, K.; MIN, J.;

SHAHABUDDIN, A.M.; HENRIKSSON, P.J.; MURRAY, F.J.; LITTLE, D.C.; DALSGAARD, A.; VAN DEN BRINK, P.J. Use of veterinary medicines, feed additives and probiotics in four major internationally traded aquaculture species farmed in Asia. Aquaculture, v.412, n.1, p.231243, 2013

ROBERFROID, M. Functional food concept and its application to prebiotics. Digestive and Liver Disease. v.34, n.2, p.105-10, 2002.

SCHELKLE, B.; DOETJES, R.; CABLE, J. The salt myth revealed: treatment of gyrodactylid infections on ornamental guppies, Poecilia reticulata. Aquaculture, v.311, p.1-4, p.74-79, 2010.

SCHELKLE, B.; SNELLGROVE, D.; CABLE, J. In vitro and in vivo efficacy of garlic compounds against Gyrodactylus turnbulli infecting the guppy (Poecilia reticulata). Veterinary Parasitology, v.198, n.1-2, p.96-101, 2013.

SHAKYA, R.N.; LABH, S.N. Medicinal uses of garlic (Allium sativum) improves fish health and acts as an immunostimulant in aquaculture.

European Journal of Biotechnology and Bioscience, v.2, n.4, p.44-47, 2014.

SHIN, S.H.; KIM, M.K. Effect of dried powders or ethanol extracts of garlic flesh and peel on lipid metabolism and antithrombogenic capacity in 16-monthold rats. The Journal of Nutrition Health and Aging, v.37, n.7, p.515524, 2004.

SYAHIDAH, A.; SAAD, C.R.; DAUD, H.M.; ABDELHADI, Y.M. Status and potential of herbal applications in aquaculture: A review. Iranian Journal of Fisheries Sciences, v.14, n.1, p.2744, 2015. 
TALPUR, A.D.; IKHWANUDDIN, M. Dietary effects of garlic (Allium sativum) on haemato-immunological parameters, survival, growth and disease resistance against Vibrio harveyi infection in Asian sea bass (Lates calcarifer). Aquaculture, v.364-365, n.5, p.6-12, 2012.

WIMBERGER, P.H. Plasticity of fish body shape. The effects of diet, development, family and age in two species of Geophagus (Pisces: Cichlidae). Biological Journal of the Linnean Society, v.45, p.197-218, 1992.

WOO, S.H.; LEE, J.H.; KIM, Y.K.; CHO, M.Y.; JUNG, S.H.; KIM, J.W.; PARK, S.I. Effects of garlic Allium sativum extract immersion on the immune responses of olive flounder Paralichthys olivaceus prechallenged with pathogenic bacteria. The Japanese Society of Fish Pathology, v. 23, p.199-209, 2010.

XIANG, X.; LIU, C.Z. Effect of allicin on growth of Colossoma brachypomum. Journal of Fish Science and Technology, v.29, p.222-225, 2002.

XUE, J.; XU, Y.; JIN, L.; LIU, G.; SUN, Y.; LI, S.; ZHANG, J. Effects of traditional Chinese medicine on immune responses in abalone, Haliotis discus hannai Ino. Fish and Shellfish Immunology, v.24, n.6, p.752-758, 2008.

ZHAO, N.N.; ZHANG, H.; ZHANG, X.C.; LUAN, X.B.; ZHOU, C.; LIU, Q.Z.; SHI, W.P.; LIU, Z.L. Evaluation of acute toxicity of essential oil of garlic (Allium sativum) and its selected major constituent compounds against overwintering Cacopsylla chinensis (Hemiptera: Psyllidae). Journal of Economic Entomology, v.106, n.3, p.1349-1354, 2013. 